equivalent of up to 40 cups of coffee, ${ }^{1}$ and none were seen in a four-generation mouse study of animals exposed to caffeine in the drinking water at rates equivalent of up to 30 cups of coffee per day. ${ }^{3}$

Caffeine also got off to a bad start in tests for mutagenicity, with positive results in both Escherichia coli ${ }^{4}$ and Drosophila. ${ }^{5}$ Nevertheless, subsequent studies in mice with the dominant lethal assay ${ }^{6} 7$ were negative, and so were cytogenetic studies in mice. ${ }^{8}$ Like almost everything else, in high concentrations caffeine is cytotoxic to human lymphocytes maintained in tissue culture ${ }^{9}$-at concentrations 100 times higher than that achievable in the blood by drinking eight cups of coffee in quick succession. At lower concentrations nothing more than slight stimulation or inhibition of mitosis occurs.

Laboratory tests of caffeine for carcinogenicity in animals, carried out a long time ago, gave essentially negative results. ${ }^{10}$ These tests, however, would be regarded as inadequate by modern standards, and there is, moreover, a theoretical possibility that caffeine could act as a cocarcinogen by catalysing the formation of $\mathrm{N}$-nitrosamines from secondary amines and nitrites in the stomach. ${ }^{11}$ To counterbalance the fear this possibility engenders there is evidence of anticarcinogenic effects of caffeine in animals exposed to known carcinogens ${ }^{12-15}$ and the fact that caffeine is rapidly and efficiently metabolised in man. ${ }^{16}$

Suspicion of a cancer risk for man has centred on the urinary tract since Cole ${ }^{1718}$ reported a higher incidence of coffeedrinking in men $(1.24: 1)$ and women $(2.58: 1)$ with bladder cancer than among matched controls, and Shennan ${ }^{19}$ drew attention to a strong correlation between coffee consumption and national mortality rates for renal cancer. The latest development in this area is a report from Sir Richard Doll and his colleagues in $\mathrm{Oxford}^{20}$ of their failure to find any association between either adenocarcinoma of the renal parenchyma (106 patients) or carcinoma of the renal pelvis (33 patients) and coffee consumption. They explain that because of the small numbers of subjects available for study a two- to threefold enhancement of cancer incidence by coffee cannot be excluded; but confidence in the reliability of their negative finding is increased by two facts. Firstly, Wynder and his colleagues $^{21}$ also saw no evidence of an association between coffee consumption and renal cancer; and, secondly, the findings of the Oxford workers are consistent with there being a 1.8-fold excess incidence of cancer of the renal pelvis in men who smoked compared with non-smokers and a definite trend towards increased risk of this form of cancer in association with heavier cigarette consumption. These latter findings were to be expected, because agents which cause cancer in the urinary bladder commonly affect the renal pelvis similarly, and there is now a well-established association between bladder cancer risk and smoking of about the same order-a twofold excess.

For the diehard puritan who cannot bring himself to accept that coffee might be harmless so far as cancer is concerned there is still the let-out that Schmauz and Cole ${ }^{18}$ saw a particularly high risk of cancer of the renal pelvis among drinkers of seven or more cups of coffee per day: none of the patients or control subjects studied by the Oxford workers consumed as much as this. But for those who, not being gluttons for the brew, find the very smell of it pleasurable and mouth-watering the news from Oxford will provide at least some grounds for comfort.

\footnotetext{
${ }^{1}$ Mulvihill, J J, Teratology, 1973, 8, 69.

2 Nishimura, H, and Nakai, K, Proceedings of the Society for Experimental Biology and Medicine, 1960, 104, 140.
}

${ }^{3}$ Thayer, P S, and Kensler, C J, Toxicology and Applied Pharmacology, 1973, 25, 169.

4 Demerec, M, Bertani, G, and Flint, J, American Naturalist, 1951, 85, 119.

5 Bateman, A J, Mutation Research, 1969, 7, 475.

${ }^{6}$ Epstein, S S, et al, Food and Cosmetics Toxicology, 1970, 8, 381.

7 Adler, I-D, Humangenetik, 1969, 7, 137.

${ }^{8}$ Adler, I-D, and Röhrborn, G, Humangenetik, 1969, 8, 81.

9 Timson, J, British fournal of Pharmacology, 1970, 38, 731 .

10 Boughton, L L, and Stoland, O O, Fournal of the American Pharmaceutical Association, 1943, 32, 187.

11 Challis, B C, and Bartlett, C D, Nature, 1975, 254, 522.

12 Weil-Malherbe, H, Biochemical fournal, 1946, 40, 351.

13 Booth, J, and Boyland, E, Biochimica et Biophysica Acta, 1953, 12, 75

14 Leiter, J, and Shear, M J, fournal of the National Cancer Institute, 1943, 3, 455.

${ }^{15}$ Rothwell, K, Nature, 1974, 252, 69.

${ }^{16}$ Axelrod, J, and Reichenthal, J, Fournal of Pharmacology and Experimental Therapeutics, 1953, 107, 519.

17 Cole, P, Lancet, 1971, 1, 1335.

${ }_{18}$ Schmauz, R, and Cole, P, fournal of the National Cancer Institute, 1974, 52, 1431.

19 Shennan, D H, British Fournal of Cancer, 1973, 28, 473.

${ }^{20}$ Armstrong, B, Garrod, A, and Doll, R, British fournal of Cancer, 1976, 33, 127.

${ }^{21}$ Wynder, E L, Mabuchi, K, and Whitmore, W F, fournal of the National Cancer Institute, 1974, 53, 1619.

\section{Anaesthetists and infection}

A recent issue of the British fournal of Anaesthesia ${ }^{1}$ contains a symposium on infection as it concerns the anaesthetist. The journal quotes an author in the $B M \mathcal{F} 103$ years $\mathrm{ago}^{2}$ who condemned the use of inhalers as "a disgusting evil," and claimed that his own was the only one cleaned between one patient and the next: "sweet seventeen is made to follow a bearded devotee to Bacchus, saturated with the smoke of cigars and the exhalations of cognac."

Within living memory little attention was paid to rubber face masks (and none to tubing or bags) unless perhaps they had been used for patients with known open tuberculosis; furthermore, perfunctory immersion in $5 \%$ phenol without adequate rinsing was known to damage the facial skin of the next patient. All this has changed, and the first paper ${ }^{3}$ in the symposium is about the "decontamination" (not necessarily sterilisation) of anaesthetic equipment, now far more complex than it used to be. The order of preference of methods of disinfection is heat, then ethylene oxide, and lastly liquid disinfectants. Apparently the problem of damage from residual disinfectant still exists, and with more reason, from ethylene oxide and glutaraldehyde, particularly with rubber materials.

The responsibilities of anaesthetists in intensive care units are discussed by Gaya, ${ }^{4}$ who argues that the extreme susceptibility to infection of patients in these units is sometimes compounded by overcrowding, inadequate staffing, and the indiscriminate use of antibiotics favouring the spread of resistant pathogens. Design is important: ideally these units should include single rooms with space for the bulky equipment required and with positive pressure ventilation for protective isolation and exhaust ventilation for containment; these two should be distinct, since a reversible ventilation system may be misused and many in any case have secondary effects elsewhere in the ward. Bulky equipment, often impossible to sterilise, tends to accumulate in ICUs, and ease of sterilisation should be a paramount requirement in its choice. Gaya discourages the use of bacteriological monitoring except for endotracheal aspirates and peritoneal dialysis fluids, two examples where it may give a timely warning and point to 
specific instead of blind antibiotic therapy should this become necessary.

The symposium also includes papers on antibiotics in the perioperative period ${ }^{5}$ and on the clinical pharmacology of antibiotics which have a more general appeal than to the anaesthetist, ${ }^{6}$ and one on septicaemia ${ }^{7}$ with emphasis on Gramnegative forms and treatment of the shock which these may induce. Two others are of direct interest in the operating theatre itself. ${ }^{8}{ }^{9}$ Waterson's account of hepatitis B as a hazard in anaesthetic practice defines the precautions necessary before, during, and after operation on a patient whose blood contained or might have contained this virus. While it is not practicable to examine every surgical patient's blood for the presence of HBAg, Waterson's formidable list gives ten indications for doing so. These include not only liver disease and other diseased states but such categories as prisoners, inmates of institutions for the mentally defective, drug addicts, prostitutes, homosexuals, and the tattooed, with a footnote that "this list should not be regarded as exhaustive."

Moudgil and Wade's review of anaesthesia and immunocompetence discusses a large amount of work, with which many people may be unfamiliar, on the effect of anaesthetics on the various functions of different types of leucocyte as well as evidence that anaesthesia increases the mortality from experimental infections. It would have been helpful if different anaesthetics could have been placed in an order of demerit from this point of view, but perhaps that is not possible.

${ }^{1}$ British Fournal of Anaesthesia, 1976, 48, (1).

2 Skinner, T, British Medical fournal, 1873, 1, 353.

${ }^{3}$ Lumley, J, British fournal of Anaesthesia, 1976, 48, 3

4 Gaya, H, British Fournal of Anaesthesia, 1976, 48, 9.

5 Darrell, J H, and Uttley, Anne H C, British fournal of Anaesthesia, 1976, 48, 13.

6 Wilkinson, P M, British fournal of Anaesthesia, 1976, 48, 25.

${ }^{7}$ Powrie, Suzanne, and Norman, J, British fournal of Anaesthesia, 1976, 48, 41.

${ }^{8}$ Waterson, A P, British fournal of Anaesthesia, 1976, 48, 21.

${ }^{9}$ Moudgil, G C, and Wade, A G, British fournal of Anaesthesia, 1976, 48, 31.

\section{Thoracic outlet compression syndrome}

Our mammalian predecessors carried their front limbs in a dependent position, so that they could stand on all four limbs. When we assumed an upright posture our arms became dependent and parallel to the trunk. This moved the nerves, arteries, and veins which leave the thorax to pass into the arm laterally and increased their angle of flexion. The combination of this acute angle and the stretching caused by the weight of our arms might be expected to give everyone a thoracic outlet syndrome, but the support given by the muscles of the shoulder girdle is normally adequate. If, however, this support fails, or if the neurovascular bundle or the bony outlet of the thoracic cage is anatomically abnormal, the nerve, the artery, and the vein may be stretched or compressed.

The symptoms of thoracic outlet compression have been attributed to cervical ribs, the first rib, the scalene muscle, compression between clavicle and rib, and compression beneath the coracoid process and the first rib. ${ }^{12}$ Undoubtedly all of these structures may cause symptoms but proving that they are the cause of a patient's complaints may be a difficult clinical problem.

The most common symptom is pain in the C8 or T1 dermatome, particularly when the arm is dependent or after carrying heavy weights. Sometimes symptoms are produced by raising the arms. The pain is felt along the whole length of the inner side of the arm and hand and is a mixture of burning and stabbing pains, paraesthesiae such as pins and needles, and numbness. If the nerve root is continually stretched or compressed the motor fibres can be damaged, producing weakness and wasting of the small muscles of the hand.

Symptoms due to compression of the subclavian artery are less common. Raynaud's phenomenon, coldness of the hand, and claudication of the forearm muscles when working with the arms above the head are the usual symptoms. Thrombus may form in the subclavian artery and emboli may block the digital arteries, causing gangrene, or a poststenotic subclavian aneurysm may develop. If the subclavian vein is compressed the arm may become swollen during heavy exercise, and the risk of an axillary vein thrombosis is increased. The confirmation of arterial or venous compression at the thoracic outlet is relatively simple with the aid of angiography.

The problem patients are those who present with pain in the arm. The possible causes of pain in the C8-T1 dermatome are legion, but the most common by far is osteoarthrosis of the cervical spine and cervical disc disease. It is essential to exclude these two conditions and other central spinal lesions before accepting the diagnosis of thoracic outlet syndrome-even in the presence of a radiologically demonstrable cervical rib. Nerve conduction studies have been claimed to be helpful ${ }^{3}$ but have been found by others to be of little value. ${ }^{4}$ Clinical tests which precipitate the symptoms-such as abduction of the arm, the military brace position, and traction on the armonly support one's suspicions: they do not confirm the diagnosis. ${ }^{5}$

If other causes of the patient's symptoms can be eliminated and there is a demonstrable cervical rib it is worthwhile exploring the neck through a supraclavicular incision and excising the rib. Again, if there is no cervical rib or other bony abnormality to suggest a fibrous band but the diagnosis of thoracic outlet syndrome seems certain, the only effective way of changing the anatomy of the thoracic outlet and relaxing any tension or pressure on the neurovascular bundle is to excise the first rib. The easiest way to do this is through an incision in the axilla. ${ }^{6}$ When the first rib is approached in this way the important structures can be pushed upwards and protected and the rib excised safely. Operating through a cervical incision is difficult and hazardous. In a report by Kremer and Ahlquist ${ }^{4}$ of 49 first rib resections for the thoracic outlet syndrome 42 patients had relief of their symptoms. Though such good results indicate the care with which the patients were selected for operation they also show that first rib resection is worthwhile for the right indication.

Usually there is time to investigate the patient fully and deliberate on the advisability of operation, but one form of thoracic outlet syndrome should be treated as an emergency. Patients who present with emboli in their fingers from a subclavian aneurysm or a stenosis due to compression should have an emergency arteriogram and exploration of their neck to remove the thrombus and repair the artery. If such a patient is not treated urgently he may have more emboli and lose his hand.

${ }^{1}$ Peet, R M, et al, Proceedings of the Mayo Clinic, 1956, 31, 281.

2 Rob, C G, and Standeven, A, British Medical fournal, 1958, 2, 709.

3 Urschel, H C, Paulson, D L, and McNamara, J J, Annals of Thoracic Surgery, 1968, 6, 1.

4 Kremer, R M, and Ahlquist, R E, American fournal of Surgery, 1975, 130, 612.

5 Telford, E D, and Mottershead, S, fournal of Bone and foint Surgery, $1948,30 B, 249$.

${ }^{6}$ Roos, D B, Annals of Surgery, 1966, 163, 354. 